\title{
Influence of terrain attributes on organic carbon stocks distribution in soil toposequences of central Poland
}

\begin{abstract}
The paper presents the results of research on the relationship between topography of undulated morainic plateau of postglacial landscape and distribution of organic carbon stocks in soil toposequences. The mean value of the soil organic carbon stocks (SOCS) for Retisols/Luvisols (RT/LV) was statistically lower than for the Phaeozems/Gleysols (PH/GL) but for RT/LV a higher variation of SOCS in comparison to PH/GL was observed. On the basis of Pearson correlation coefficient, the cartographic depth to water (DTW), the topographic wetness index (TWI) and the saga wetness index (SWI) were the most strongly correlated with the SOCS from among 13 analysed topographic attributes. In addition, the DTW was more correlated with SOCS than other topographic variables. Moreover, the DTW based on the channel networks with 2 ha flow initiation thresholds better correlate with SOCS than DTW obtained on the basis of channel networks with 1 ha and 4 ha flow initiation thresholds. Using Stepwise multiple regression analysis (SMLR), we concluded that the topographic attributes controlling the soil water content and slope shape had most impact on SOCS of the undulated morainic plateau of agricultural ecosystem. In this landform, where the RT/LV and PH/GL soil sequences dominate, the SOCS can be estimated by the DTW, TWI and GC (general curvature) with an estimation error of $0.21 \mathrm{~kg} \mathrm{~m}^{-2}$. In view of the increasing availability of LiDAR data and power of GIS tools, the use of topographic metrics to assess spatial variability of soil properties will play an increasingly important role in the estimation of soil properties.
\end{abstract}

Keywords: soil organic carbon stocks, soil toposequence, terrain attributes, postglacial landscape, morainic plateau

\section{INTRODUCTION}

Soils play an important role in the global cycle of carbon via the accumulation and decomposition of soil organic carbon (SOC). Soil organic carbon stocks (SOCS) are about 3 and 4 times larger than atmospheric carbon and biotic carbon storages respectively (Lal 2004). The SOC contents and the SOCS have also a large impact on other physical and chemical properties, thus affecting soil quality. Therefore, the assessment of SOC and SOCS is of great importance (Qin et al. 2016).

In recent years, a range of techniques has been developed to predict and map SOC content and SOCS using the scheme of digital soil mapping (DSM) proposed by McBratney et al. (2003). Minasny et al. (2013) delivered a comprehensive review of the SOC content and the SOCS modelling for various scales and the DSM techniques. The development of GIS tools, the access to the LiDAR data and the progress of topographic metrics (attributes) allow better understanding of mechanisms underlying topographic impact on SOCS and other soil properties in agricultural ecosystems (Murphy et al. 2011, Li et al. 2018). Several studies have indicated that topography is one of the most important factors influencing the SOC and the SOCS, especially at regional and landscape levels (Taghizadeh-Mehrjardi et al. 2016, Qin et al. 2016, Fissore et al. 2017, Zhu et al. 2017, RománSánchez et al. 2018, Li et al. 2018, Wang et at. 2018).

Numerous research results indicate that for mountainous landscapes, there is a relationship between the slope aspect and the SOC content and the SOCS (Qin et al. 2016, Zhu et al. 2017, RománSánchez et al. 2018). In turn, Drewnik et al. (2016) do not confirm this pattern for the Western Bieszczady Mountains (southeastern Poland). That the weak statistically significant tendencies concerning SOCS accumulated in soils of different altitudinal zones of the Karkonosze Mountains are due to inadequate sampling methodology was also stated by Szopka et al. 2016. Román-Sánchez et al. (2018) ranked topographic variables for the needs of modelling SOC content in mountain regions. They pointed out that, after insolation, the following variables had an impact on SOC content, curvature, TPI (topographic position index), SPI (steam power index) and slope gradient. In addition to remote sensing indices, Taghizadeh-Mehrjardi et al. (2016) used the topographic wetness index (TWI) and the slope gradient for piedmont hillslopes for modelling SOC content. The TWI, in addition to other topographic indices, has been successfully used to model SOC content in postglacial areas with various soil parent material $(\mathrm{Obu}$ 
et al. 2017, Li et al. 2018, Wang et al. 2018). The TWI is effective in identifying wet areas and investigating slope water redistribution and thereby in the determination of spatial distributions of soil water content along slopes (Lang et al. 2013). Murphy et al. (2007) proposed a new topographic metric called the cartographic depth to water (DTW) for mapping wetland. This topographic index has a higher potential for applications in soil studies than the TWI (Murphy et al. 2009) because topographically depended soil properties are better correlated with the DTW in comparison to the TWI (Murphy et al. 2011).

The study objectives were: 1) to investigate the relationship between topography of postglacial landscape and organic carbon stocks distribution in agricultural field soil toposequences, 2) to use topographic variables to predict soil carbon stocks.

\section{MATERIALS AND METHODS}

The investigated area is located in the central part of the Poznan Lakeland, within an undulated morainic plateau bordered directly from the south by a hum- mocky morainic plateau formed on the hinterland of the maximum glacier range of the Poznan phase of Vistulian glaciation (Kasprzak 1988). The study area is located at about $30 \mathrm{~km}$ NE from the Poznań city (Fig. 1A). The spatial variability of soil properties were estimated on 100 ha arable field, being under long-term annual conventional tillage. Field work was carried out in two stages. In the first, soil variation was established by scatter-point method (pits and boreholes) and then the representative pedons were localized. In the second stage, the two transects (A and B) were delineated. In 52 open pits along the transects, the soil morphology was determined by identification of genetic and diagnostic horizons, boundaries between horizon sequences, soil colour, structure, consistency, reaction with hydrochloric acid as well as establishing taxonomic soil classification. From each soil horizon, the monolithic soil samples were collected for laboratory analyses and undisturbed soil samples were taken to determine the bulk density with four replications. Each the 52 pits were georeferenced with horizontal accuracy of $0.03 \mathrm{~m}$ by TC 500 Leica global positioning system (GPS) receivers. The
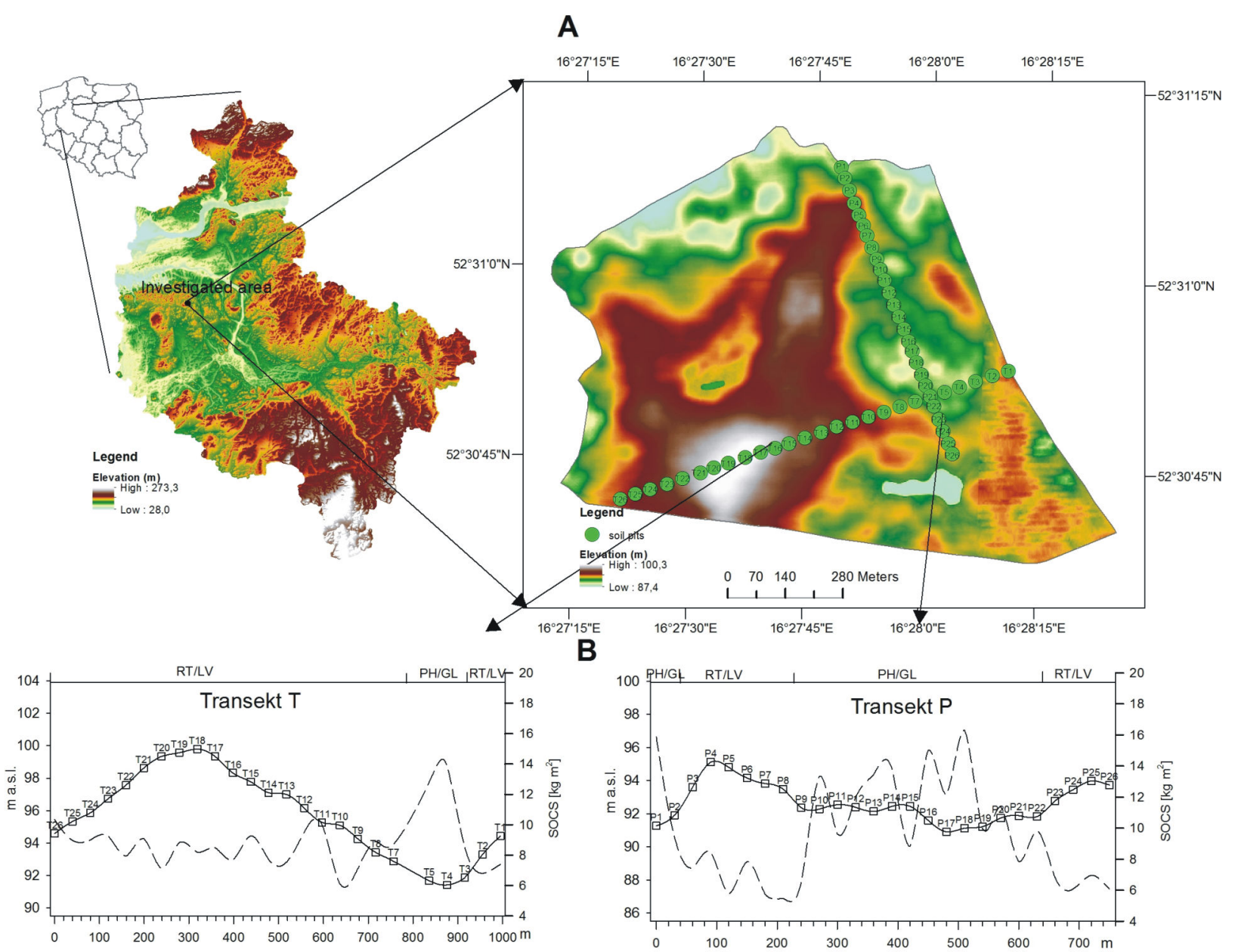

FIGURE 1. Location of investigated area (A) and the distribution of SOCS in transects (B) 
samples were air-dried and ground to pass through $2 \mathrm{~mm}$ sieve prior to analysis. In laboratory studies, the silt and clay fractions were determined by the areometric method, according to the Polish Standard PN-R-04032 (1998), while the sand particles were distinguished by the sieve method with wet fractioning. The division into textural classes was made according to the PTG (2009). The organic carbon content in fine earth was determined by wet oxidation with dichromate according to the Walkley-Black method (Nelson and Sommers 1982). To ensure the accuracy of the measurement results, all samples were analyzed three times and the data were averaged. The soil organic carbon stocks (SOCS) $\left(\mathrm{kg} \mathrm{m}^{-2}\right)$, were calculated using the following equation (Román-Sánchez et al. 2018):

$$
\operatorname{SOCS}=\sum_{\mathrm{i}=1}^{\mathrm{n}} \operatorname{SOCC}_{\mathrm{i}} \mathrm{BD}_{\mathrm{i}} \mathrm{z}_{\mathrm{i}} 10^{-3}
$$

were $\mathrm{SOCC}_{\mathrm{i}}$ is the organic carbon content $\left(\mathrm{g} \mathrm{kg}^{-1}\right)$, $\mathrm{BD}_{\mathrm{i}}$ is the bulk density $\left(\mathrm{kg} \mathrm{m}^{-3}\right)$, and $\mathrm{z}_{\mathrm{i}}$ is the horizon or layer thickness (m), $\mathrm{i}$ is the soil horizon or layer.

Topographic metrics (attributes) were derived from DEM with $5 \mathrm{~m}$ resolution created from LiDAR data. To reduce noise caused by local variation, the DEMs were filtered twice using a $5 \times 5$ low pass filter. The FILL function was used to generate a DEM free of depressions (Tarboton 1997). The filled DEM was then used to determine elevation, flow direction with $\mathrm{D} \infty$ algorithm (multiple flow direction), aspect, profile curvature $(\mathrm{PrC})$, plan curvature $(\mathrm{PlC})$, general curvature (GC), slope gradient, flow accumulation, topographic wetness index (TWI), SAGA wetness index (SWI), stream power index (SPI) and slope length factor (LS) (Beven et al. 1984, Moor et al. 1991, Tarboton 1997, Böehner and Selige 2006). In addition to the above-mentioned topographic metrics, the cartographic depth-to-water (DTW) was determined (Murphy et al. 2007). The DTW refers to the least-cost depth or elevation difference (in metres) to the nearest open water locations such as the DEMderived streams, lakes, pools, ponds, or shoreline (Murphy et al., 2009; 2011). The DTW was calculated for channel networks with 4 ha $\left(\right.$ DTW $\left._{4}\right), 2$ ha $\left(\right.$ DTW $\left._{2}\right)$ and 1 ha $\left(\right.$ DTW $\left._{1}\right)$ flow initiation thresholds for the $\mathrm{D} \infty$ algorithm (single flow direction).

Statistical analyses for soil map units in the form of complexes (Soil Science Division Staff 2017) were performed using STATISTICA (version 13) (StatSoft, Inc., USA). In the two transects analyzed, the Retisols/Luvisols (RT/LV) and the Phaeozems/Gleysols (PH/GL) complexes were distinguished, which create a regular and repeating pattern on the landscape of undulated ground moraine. Each of the variables (topographic metrics and SOCS) were tested for normality using the Kolmogorov-Smirnov test. Relationships between SOCS and topographic attributes were analyzed using the Pearson correlation coefficient (R). We also used the U Manna-Whitney'a test to determine the significant differences between the SOCS of the distinguished soil complexes as well as transects. This nonparametric test was used because within distinguished soil complexes/transects, though these being a grouping of variables, the SOCS did not show a normal distribution or the size of the sample of data was too small. Stepwise multiple regression analysis (SMLR) was used to study the statistical relationship between the SOCS and topographic factors, and to build a model that allows us to estimate SOCS based on topography metrics.

\section{RESULTS AND DISCUSSION}

The pedological cross-section presented in Figure 1 clearly shows that transects run through the terrain, which is diversified in terms of relief. In these transects, the Retisols/Luvisols (RT/LV) and the Phaeozems/Gleysols (PH/GL) create characteristic soil sequences along slopes which confirmed earlier observations within the Polish Lowlands (Marcinek and Wiślańska 1984, Komisarek 2000, Podlasiński 2013, Świtoniak 2014, Kozłowski and Komisarek 2016, Kozłowski et al. 2018). The relationship between SOCS values and the soil position in a relief is pronounced. The SOCS increased in pediments and depressions and decreased in summits and shoulders (Fig. 1B). In the RT/LV formed within higher part of slopes the SOCS values ranged from 4.3 to $11.6 \mathrm{~kg} \mathrm{~m}^{-2}$ and from 4.6 to $10.35 \mathrm{~kg} \mathrm{~m}^{-2}$ for transects $\mathrm{P}$ and $\mathrm{T}$ respectively. In soils occupying a lower position in the relief $(\mathrm{PH} / \mathrm{GL})$, the SOCS were clearly greater and ranged from 6.3 to $38.1 \mathrm{~kg} \mathrm{~m}^{-2}$. Similar variation in SOCS values was obtained within sequence of erosional/colluvial soils located on Vistula Valley slopes (Świtoniak et al. 2015). Data presented in

TABLE 1. Basic statistics of the SOCS in transects P and T

\begin{tabular}{llrrrl}
\hline \multirow{2}{*}{ Transect } & $\begin{array}{l}\text { Soil } \\
\text { complex }\end{array}$ & Mean & Median & SD & CV \\
\cline { 3 - 6 } & & $\mathrm{kg} \cdot \mathrm{m}^{-2}$ & & & $\%$ \\
\hline $\mathrm{P}$ & $\mathrm{RT} / \mathrm{LV}$ & 7.2 & 6.1 & 2.2 & 30.5 \\
\cline { 2 - 6 } & $\mathrm{PH} / \mathrm{GL}$ & 12.3 & 11.1 & 7.9 & 64.3 \\
\hline $\mathrm{T}$ & $\mathrm{RT} / \mathrm{LV}$ & 8.2 & 8.6 & 1.7 & 20.7 \\
\cline { 2 - 6 } & $\mathrm{PH} / \mathrm{GL}$ & 12.1 & 12.8 & 3.2 & 26.7 \\
\hline $\mathrm{P}+\mathrm{T}$ & $\mathrm{RT} / \mathrm{LV}$ & 7.9 & 8.1 & 1.9 & 23.9 \\
\cline { 2 - 6 } & $\mathrm{PH} / \mathrm{GL}$ & 12.2 & 11.4 & 7.3 & 59.5 \\
\hline
\end{tabular}

$\mathrm{SD}$ - the standard deviation, $\mathrm{CV}$ - the coefficient of variation. 
Table 1 show that the PH/GL were characterized by a higher variation of the SOCS values than the RT/LV. In the RT/LV the coefficient of variation $(\mathrm{CV})$ values of SOCS were $30.5 \%$ and $26.7 \%$ whereas in the $\mathrm{PH} / \mathrm{GL}$ $64.3 \%$ and $26.7 \%$ for transect $\mathrm{T}$ and $\mathrm{P}$ respectively. In the transect $\mathrm{P}$ the mean SOCS were $7.2 \mathrm{~kg} \mathrm{~m}^{-2}$ for the RT/LV soils and $12.3 \mathrm{~kg} \mathrm{~m}^{-2}$ for the $\mathrm{PH} / \mathrm{GL}$ soils whereas in the transect $\mathrm{T}$ the mean values of SOCS were 8.2 and $12.1 \mathrm{~kg} \mathrm{~m}^{-2}$ for the RT/LV and the PH/GL respectively. Both in the $\mathrm{T}$ and the $\mathrm{P}$ transect soils, statistically significant differences of the mean values of SOCS were found between the RT/LV and the PH/GL (Table 2). Statistical analysis did not show significant differences of the mean SOCS values of the RT/LV between the $\mathrm{T}$ and the $\mathrm{S}$ transects, as in the case of the PH/GL. The mean value of the SOCS for all analysed RT/LV of two transects was $7.9 \mathrm{~kg} \mathrm{~m}^{-2}$ whereas it was $12.2 \mathrm{~kg} \mathrm{~m}^{-2}$ for PH/GL.

Table 3 shows the basic statistical values of the topographical parameters of the analysed transects, while Figure 2 shows the spatial distribution of their values. The RT/LV have been formed in higher slope parts whereas the PH/GL in a lowest. The elevation for the RT/LV ranged from 93.27 to $100.30 \mathrm{~m}$ a.s.1. with the mean $96.16 \mathrm{~m}$ a.s.l. while for the $\mathrm{PH} / \mathrm{GL}$ from 91.43 to $93.02 \mathrm{~m}$ a.s.l (the mean $92.32 \mathrm{~m}$ a.s.l). The mean slope gradient was a slightly higher for the $\mathrm{PH} / \mathrm{GL}$ in comparison to the RT/LV. The values of DWT were higher for the RT/LV than for the PH/GL, both for DWT calculated on the basis of 1 ha, 2 ha and 4 ha flow initiation thresholds. This indicates that the PH/GL have been formed under poor drainage conditions caused by a shallow groundwater table (PSC 2011). The TWI and the SWI values were higher for the PH/GL than for the RT/LV. The mean vales of the TWI and the SWI of the RT/LV were 6.8 and 5.3, whereas for PH/GL 9.8, and 6.2, respectively.

A Pearson correlation analysis was performed to check the relationships between the Ln-transformed SOCS with the topographical variables (Table 4). The

TABLE 2. The result of U Manna-Whitney'a test of the significant differences of the SOCS (statistical significance)

\begin{tabular}{|c|c|c|c|c|c|c|c|}
\hline \multirow[t]{2}{*}{ Transect } & \multirow{2}{*}{$\begin{array}{l}\text { Soil } \\
\text { complex }\end{array}$} & \multicolumn{2}{|l|}{$\mathrm{P}$} & \multicolumn{2}{|l|}{$\mathrm{T}$} & \multicolumn{2}{|l|}{$\mathrm{P}+\mathrm{T}$} \\
\hline & & $\mathrm{RT} / \mathrm{LV}$ & $\mathrm{PH} / \mathrm{GL}$ & $\mathrm{RT} / \mathrm{LV}$ & PH/GL & $\mathrm{RT} / \mathrm{LV}$ & $\mathrm{PH} / \mathrm{GL}$ \\
\hline \multirow[t]{2}{*}{$\mathrm{P}$} & & $\mathrm{RT} / \mathrm{LV}$ & & & & & \\
\hline & $\mathrm{PH} / \mathrm{GL}$ & $0.0014 *$ & & & & & \\
\hline \multirow[t]{2}{*}{$\mathrm{T}$} & $\mathrm{RT} / \mathrm{LV}$ & 0.0687 & $0.0042 *$ & & & & \\
\hline & $\mathrm{PH} / \mathrm{GL}$ & $0.0343 *$ & 0.9783 & $0.0241^{*}$ & & & \\
\hline \multirow[t]{2}{*}{$\mathrm{P}+\mathrm{T}$} & $\mathrm{RT} / \mathrm{LV}$ & - & - & - & - & & \\
\hline & $\mathrm{PH} / \mathrm{GL}$ & - & - & - & - & 0.0014* & \\
\hline
\end{tabular}

*statistical significance.
TABLE 3. Basic statistics (mean - median and minimum maximum) of topographic variables for $\mathrm{RT} / \mathrm{LV}$ and $\mathrm{PH} / \mathrm{GL}$

\begin{tabular}{|c|c|c|}
\hline \multirow[t]{2}{*}{ Topography metrics } & \multicolumn{2}{|l|}{ Soil complex } \\
\hline & $\mathrm{RT} / \mathrm{LV}$ & PH/GL \\
\hline \multirow[t]{2}{*}{ Elevation (m a.s.l.) } & $96.16-95.64$ & $92.32-92.27$ \\
\hline & $93.27-100.30$ & 91.43-93.02 \\
\hline \multirow[t]{2}{*}{ Slope gradient $(\%)$} & $2.8-2.7$ & $0.4-5.3$ \\
\hline & $3.4-2.2$ & $0.3-12.8$ \\
\hline \multirow[t]{2}{*}{ DWT1 (m) } & $3.0-2.8$ & $0.4-5.3$ \\
\hline & $1.2-1.3$ & $0.3-2.1$ \\
\hline \multirow[t]{2}{*}{ DWT2 (m) } & 4.6-4.9 & $2.6-2.4$ \\
\hline & $0.9-6.6$ & $0.6-4.6$ \\
\hline \multirow[t]{2}{*}{ DWT4 (m) } & 4.3-4.5 & $2.6-2.4$ \\
\hline & $0.7-6.7$ & $0.8-4.6$ \\
\hline \multirow[t]{2}{*}{ SWI (-) } & $\underline{5.3-5.3}$ & $6.2-6.3$ \\
\hline & $3.8-6.7$ & $5.0-7.9$ \\
\hline \multirow[t]{2}{*}{ TWI (-) } & $6.8-6.5$ & $9.8-9.4$ \\
\hline & $4.9-10.4$ & $6.4-17.5$ \\
\hline \multirow[t]{2}{*}{ GC (-) } & $0.0009-0.0012$ & $0.0025-0.0000$ \\
\hline & $-0.0248-0.0216$ & $-0.0288-0.0752$ \\
\hline \multirow[t]{2}{*}{ PlC (-) } & $0.0125-0.0169$ & $0.0003-0.0045$ \\
\hline & $-0.2731-0.4566$ & $-0.1368-0.1624$ \\
\hline \multirow[t]{2}{*}{ SPI (-) } & $6.23-4.41$ & $6.48-0.07$ \\
\hline & $0.10-17.48$ & $0.01-64.42$ \\
\hline \multirow[t]{2}{*}{ Aspect (radians) } & $2.74-2.19$ & $3.40-3.42$ \\
\hline & $0.06-6.21$ & $0.11-6.24$ \\
\hline \multirow[t]{2}{*}{ LS (-) } & 0.1349-0.0005 & $0.1774-0.1843$ \\
\hline & $0.0002-1.7630$ & $0.0874-0.3746$ \\
\hline
\end{tabular}

$\ln$ (natural logarithm)-transformed SOCS were most significantly correlated with all DTW $\left(\right.$ DTW $_{1}$, DTW $_{2}$, $\mathrm{DTW}_{4}$ ) where the highest value of Pearson's correlation coefficient $(\mathrm{R})$ was for the $\mathrm{DTW}_{2}(\mathrm{R}=-0.651)$ and the lowest for the $\mathrm{DTW}_{1}(\mathrm{R}=-0.553)$. These indicate that the $\mathrm{DTW}_{2}$ based on the channel networks with 2 ha flow initiation thresholds better correlate with SOCS than DTW, obtained on the basis of the channel networks with 1 ha and 4 ha flow initiation thresholds. Murphy et al. (2011), analysing the relationship between DTW and soil types, soil drainage and other selected soil properties, including the soil carbon content, obtained the best correlation with the 4-ha flow-initiation DTW pattern. In addition to DTW in the analysed soil toposequences, there are significant relationships between SOCS, and TWI and SWI $(\mathrm{R}=0.573$ and $\mathrm{R}=0.463$, respectively). With an increase values of TWI, the SOCS of analysed toposequences show an increasing trend similar to 
TABLE 4. Correlation coefficients between terrain variables and SOCS

\begin{tabular}{llllllllllllll}
\hline \multicolumn{1}{l}{ Terrain attributes } \\
\hline & Elevation Slope & DWT1 & DWT2 & DWT4 & SWI & TWI & GC & PIC & PrC & SPI & Aspect & LS \\
\hline SOCS & $-0.380^{*}$ & 0.209 & $-0.570^{*}$ & $-0.651^{*}$ & $-0.637^{*}$ & $0.463^{*}$ & $0.573^{*}$ & $0.315^{*}$ & -0.024 & $0.339^{*}$ & 0.028 & 0.082 & 0.102 \\
\hline
\end{tabular}

*statistical significant at a level of significance 0.05 .

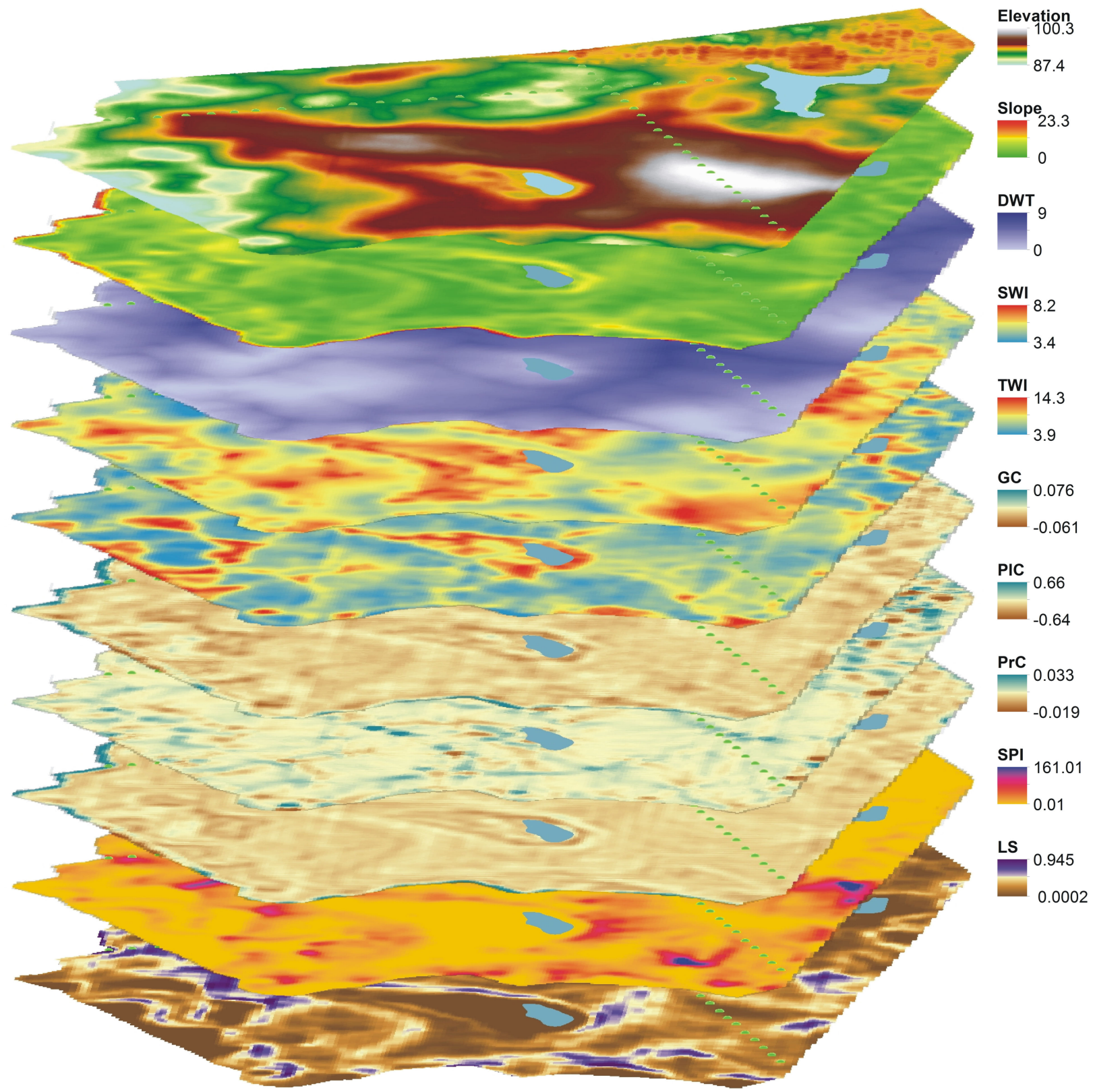

FIGURE 2. Spatial distribution of basic topographic attributes

that of DTW. The TWI is effective at identifying wetlands and investigating spatial distributions of soil moisture along slopes (Lang et al. 2013). Li et al. (2018), Wang et al. (2018) also found positive correlation between SOCS and TWI. Xin et al. (2016) in their studies conducted in Luoyugou watershed gully-hill of the Chinese Loess Plateau do not confirm these pattern but the soils of this area have been profoundly disturbed by human activity, particularly by the conversion from sloped land to terraced cropland. In turn, Murphy et al. (2009) suggest that DTW has a higher potential for applications in soil researches than TWI because most of soil properties topographically depended, are more correlated with 
DTW than with TWI (Murphy et al. 2011). In our study, significant relations were also found between Elevation, PrC and GC and SOC stocks but these dependencies have correlation coefficient values lower $(-0.380,0.339$ and 0.315 respectively) than those obtained for DTW and TWI. Despite this, these coefficients were statistically significant and indicate that the slope shape expressed by $\operatorname{PrC}$ and GC has also impact on SOCS. Insignificant linear correlations were observed between SOCS and Aspect, Slope, LS, PIC and SPI indicating that these topographic attributes were likely not an efficient controller of SOCS within analysed soils. In turn, Li et al. (2018) observed significant correlations between SOCS and Slope, GC, LS, PIC, PrC and SPI. Qin et al. (2016) and Zhu et al. (2017) for mountain terrain concluded that the aspect has a significant impact on the SOC content and SOC stocks. Drewnik et al. (2016) on the basis on research carried out in the Western Bieszczady Mountains (southeastern Poland) deduced that insolation, directly the slope exposure depended, was not the main reason for the differentiation of SOCS between the south and north-facing slopes.

Using the stepwise multiple linear regression analysis (SMLR), we built up model with ln-transformed SOCS as dependent variables. For this analysis, all the topographic attributes were taken as independent variables. The result indicates that only three variables, i.e. DTW 2 , TWI and GC were statistically significant topographical variables allowing the estimation of SOCS in analysed soil sequences (Table 5). Among them, DTW had larger share in the estimation of SOCS rather than TWI and GC, as evidenced by the values of standardized regression coefficient. The SMLR model explains $67 \%$ of SOCS variability in analysed soils of toposequences with an estimation error of $0.21 \mathrm{~kg} \mathrm{~m}^{-2}$. In our study, we indicated the possibility of estimating SOCS on the basis of topographic attributes for the soil landscape of undulating ground moraine made of boulder clay where the Retisols/Luvisols (RT/LV) and the Phaeozems/Gleysols (PH/GL) create characteristic soil sequences. Li et al. (2018) and Wang et al. (2018) modelled SOCS based on topographic variables and using the SMLR received the value of the determination coefficient similar to this obtained in our study. Wang et al. (2018) used independent variables such as Aspect, Elevation, Slope, TWI, CA (Catchment Area) and Landsat TM bands (B3, B4 and B5) while Li et al. (2018) used TWI, FPL (Flow Path Length), GC, Slope, LS, DI (Downslope Index), RePC1 and RePC2 (topographic relief component 1 and 2, respectively) to estimate SOCS. This indicates the need for further researches into the impact of topography on SOCS for various landforms. In addition, the development of GIS tools, the availability of LiDAR data and the improvement of topographic variables will allow better understanding of mechanisms underlying topographic impact on SOCS and other soil properties in agricultural ecosystems (Murphy et al. 2011, Li et al. 2018).

\section{CONCLUSIONS}

In this study, we investigated the spatial distribution SOC stocks within undulating ground moraine of Poznań Lakeland in relation to topographic attributes. The research was conducted in the soils of two transects running through undulated moraine plateau where the Retisols/Luvisols (RT/LV) and the Phaeozems/Gleysols (PH/GL) form a regular and repetitive patterns.

The mean value of SOCS for all analyzed RT/LV was statistically lower than for PH/GL but for RT/LV a higher variation of SOCS in comparison to $\mathrm{PH} / \mathrm{GL}$ was observed. In summary, obtained results suggest that the topography significantly impacts spatial patterns of soil variability and resulting SOCS distribution. From a general perspective, we have shown that the DTW, TWI and SWI were the most strongly correlated with the SOCS from the analysed topographic attributes. In addition, the DTW was more correlated with SOCS than other topographic variables. Moreover, the DTW based on the channel networks with 2 ha flow initiation thresholds better correlate with SOCS than DTW obtained on the basis of the channel networks with 1 ha and 4 ha flow initiation thresholds.

The topographic attributes controlling the soil water content and a slope shape mainly had an impact on SOCS of agricultural ecosystem of undulated morainic plateau. In this landform, where the RT/LV and PH/GL had been formed, the SOCS can be estimated by DTW, TWI and GC with an estimation error of $0.21 \mathrm{~kg} \mathrm{~m}^{-2}$. In view of the increasing availa- 
bility of LiDAR data and the increasing power of GIS tools, detailed relations between soil properties and topographic metrics will play an increasingly important role.

\section{REFERENCES}

Beven K., Kirkby M., Schofield N., Tagg A., 1984. Testing a physically-based flood forecasting model (TOPMODEL) for three UK catchments. Journal of Hydrology 69(1): 119-143.

Böehner J., Selige T., 2006. Spatial prediction of soil attributes using terrain analysis and climate regionalisation. Goettinger Geographische Abhandlungen 115: 13-28.

Drewnik M., Musielok Ł., Stolarczyk M., Mitka J., Gus M., 2016. Effects of exposure and vegetation type on organic matter stock in the soils of subalpine meadows in the Eastern Carpathians. Catena 147: 167-176.

Fissore C., Dalzell B.J., Berhe A.A., Voegtle M., Evans M., Wu A., 2017. Influence of topography on soil organic carbon dynamics in a Southern California grassland. Catena 149: 140-149.

Kasprzak L., 1988. Mechanism differentiation in the formation of marginal zones, Leszno and Poznan phases of the last glaciation, Great Polish Lowland (in Polish). Dokumentacja Geograficzna. PAN 5-6: pp. 159.

Komisarek J., 2000. Kształtowanie się właściwości gleb płowych i czarnych ziem oraz chemizmu wód gruntowych w katenie falistej Pojezierza Poznańskiego. Roczniki Akademii Rolniczej w Poznaniu. Rozprawy Naukowe 307: 143 pp.

Kozłowski M., Komisarek J., 2016. Soil sequences along a slope of the Opalenica Plain. Journal of Ecological Engineering 17(1): 69-76.

Kozłowski M., Komisarek J., Wiatrowska K., 2018. Temporal variability of water table depth in topohydrosequence of undulating ground moraine in central Poland. Polish Journal of Environmental Studies 27(5): 2097-2106.

Lal R., 2004. Soil carbon sequestration impacts on global climate change and food security. Science 304: 1623-1627.

Lang M.W., McCarty G.W., Oesterling R., Yeo I.Y., 2013. Topographic metrics for improved mapping of forested wetlands. Wetlands 33: 141-155.

Li X., McCarty G., Karlen D., Cambardella C., 2018. Topographic metric predictions of soil redistribution and organic carbon in Iowa cropland fields. Catena 160: 222-232.

Marcinek J., Wiślańska A., 1984. Asocjacje czarnych ziem i gleb płowych falistej moreny dennej Równiny Kościańskiej. Roczniki Akademii Rolniczej w Poznaniu 149: 65-81.

McBratney A.B., Mendonça-Santos, M.L., Minasny B., 2003. On digital soil mapping. Geoderma 117: 3-52.

Minasny B., McBratney A.B., Malone B.P., Wheeler I., 2013. Digital mapping of soil carbon. Advances in Agronomy 118: $1-47$.

Moore I.D., Grayson R.B., Ladson A.R., 1991. Digital terrain modelling: a review of hydrological, geomorphological, and biological applications. Hydrological Processes 5(1): 3-33.

Murphy P.N.C., Ogilvie J., Arp P.A., 2009. Topographic modelling of soil moisture conditions: a comparison and verification of two models. European Journal of Soil Science 60: 94-109.

Murphy P.N.C., Ogilvie J., Connor K., Arp P.A., 2007. Mapping wetlands: A comparison of two different approaches for New Brunswick, Canada. Wetlands 27: 846-854.
Murphy P.N.C., Ogilvie J., Meng F.-R., White B., Bhatti J.S., Arp P.A., 2011. Modelling and mapping topographic variations in forest soils at high resolution: a case study. Ecological Modelling 222: 2314-2332.

Nelson D.W., Sommers L.E., 1982. Total carbon, organic carbon and organic matter. [In:] Methods of soil analysis (Page A. L., Miller R.H., Keeney D.R., Editors). Part 2. Agronomy Monographs 9. Madison, SSSA Book Series no. 5: 539-579.

Obu J., Lantuit H., Myers-Smith I., Heim B., Wolter J., Fritz M., 2017. Effect of terrain characteristics on soil organic carbon and total nitrogen stocks in soils of Herschel Island, Western Canadian Arctic. Permafrost and Periglacial Processes 28: 92-107.

PN-R-04032. 1998. Gleby i utwory mineralne. Pobierania próbek i oznaczanie składu granulometrycznego. Polski Komitet Normalizacyjny, Warszawa.

Polish Soil Classification (Systematyka gleb Polski), 2011. Roczniki Gleboznawcze - Soil Science Annual 62(3): 1-193.

Polskie Towarzystwo Gleboznawcze, 2009. Particle size distribution and textural classes of soils and mineral materials classification of Polish Society of Soil Science 2008. Roczniki Gleboznawcze - Soil Science Annual 60(2): 5-16.

Qin Y., Feng Q., Holden N.M., Cao J., 2016. Variation in soil organic carbon by slope aspect in the middle of the Qilian mountains in the upper Heihe river basin, China. Catena 147: 308-314.

Podlasiński M., 2013. Denudation of Anthropogenic Impact on the Diversity of Soil Cover and Its Spatial Structure in the Agricultural Landscape of Moraine. West Pomeranian University of Technology, Szczecin (in Polish with English summary).

Román-Sánchez A., Vanwalleghem T., Peńa A., Laguna A., Giráldez J.V., 2018. Controls on soil carbon storage from topography and vegetation in a rocky, semi-arid landscapes. Geoderma 311: 159-166.

Soil Science Division Staff, 2017. Soil survey manual. C. Ditzler, K. Scheffe, and H.C. Monger (Editors.). USDA Handbook 18. Government Printing Office, Washington, D.C.

Taghizadeh-Mehrjardi R., Nabiollahi K., Kerry R., 2016. Digital mapping of soil organic carbon at multiple depths using different data mining techniques in Baneh region, Iran. Geoderma 266: 98-110.

Tarboton D.G., 1997. A new method for the determination of flow directions and upslope areas in grid digital elevation models. Water Resources Research 33: 309-319.

Szopka K., Kabała C., Karczewska A., Jezierski P., Bogacz A., Waroszewski J., 2016. The pools of soil organic carbon accumulated in the surface layers of forest soils in the Karkonosze Mountains, SW Poland. Soil Science Annual 67, 2: 46-56.

Świtoniak M., 2014. Use of soil profile truncation to estimate influence of accelerated erosion on soil cover transformation in young morainic landscapes, North-Eastern Poland. Catena 116: $173-184$.

Świtoniak M., Dąbrowski M., Łyszkiewicz A., 2015. The Influence of Human-induced Erosion on the Soil Organic Carbon Stock in Vineyards of Fordon Valley. Polish Journal of Soil Science 48, 2: 197-211.

Wang S., Zhuang Q., Jia S., Jin X., Wang Q., 2018. Spatial variations of soil organic carbon stocks in a coastal hilly area of China. Geoderma 314: 8-9. 
Xin Z.B., Qin Y.B., Yu X.X., 2016. Spatial variability in soil organic carbon and its influencing factors in a hilly watershed of the Loess Plateau, China. Catena 137: 660-669.

Zhu M., Feng Q., Qin Y., Cao J., Li H., Zao Y., 2017. Soil organic carbon as functions of slope aspects and soil depths in a semiarid alpine region of Northwest China. Catena 152: 94102.
Received: August 27, 2018

Accepted: November 15, 2018

Associated editor: A. Lachacz

\title{
Wpływ atrybutów topograficznych na ksztaltowanie się zasobów węgla organicznego $\mathrm{w}$ glebach układu toposekwencyjnych w centralnej Polsce
}

\begin{abstract}
Streszczenie: W pracy przedstawiono wyniki badań nad zależnością pomiędzy topografią polodowcowego krajobrazu falistej wysoczyzny morenowej a rozmieszczeniem zasobów węgla organicznego w glebach układów toposekwencyjnych. Średnia wielkość zasobów węgla organicznego w glebach (SOCS) Retisols/Luvisols (RT/LV) była statystycznie niższa niż w glebach Phaeozems/ Gleysols (PH/GL), ale w RT/LV obserwowano wyższą zmienność SOCS w porównaniu z PH/GL. Na podstawie wartości współczynnika korelacji Pearsona, kartograficzna głębokość wód gruntowych (DTW), topograficzny wskaźnik wilgotności (TWI) i wskaźnik wilgotności SAGA (SWI) były najsilniej skorelowane z SOCS spośród 13 analizowanych atrybutów topograficznych. Ponadto DTW była bardziej skorelowana z SOCS niż inne zmienne topograficzne. DTW obliczona dla sieci cieków generowanych przy 2 ha akumulacji spływu wody koreluje lepiej z SOCS niż DTW uzyskana na podstawie sieci cieków z 1 ha i 4 ha progami ich inicjacji. Wykorzystując analizę regresji wielokrotnej krokowej postępującej (SMLR), wykazano, że atrybuty topograficzne charakteryzujące potencjalne warunki wilgotnościowe terenu i kształt stoków, miały główny wpływ na rozkład SOCS w falistej morenie dennej. W tej formie terenu, gdzie dominują sekwencje RT/LV i PH/GL, SOCS mogą być oszacowany na podstawie DTW, TWI i GC (całkowita krzywizna stoku) z błędem oszacowania $0,21 \mathrm{~kg} \cdot \mathrm{m}^{-2}$. W związku z rosnącą dostępnością danych LiDAR i postępującą siłą narzędzi GIS, coraz ważniejszą rolę będzie odgrywać użycie wskaźników topograficznych do oceny przestrzennego zróżnicowania właściwości gleb i do oszacowania ich wielkości.
\end{abstract}

Stowa kluczowe: zasoby węgla organicznego, toposekwencja gleb, wskaźniki topograficzne, krajobraz polodowcowy, wysoczyzna morenowa 